\title{
Epidemiological and pathological aspects of salmonellosis in cattle in southern Brazil
}

\author{
Franciéli Adriane Molossi ${ }^{*}{ }^{*}$ Bianca Santana de Cecco $^{1}$ (i) Luan Cleber Henker ${ }^{1}$ (i) \\ Thainã Piccolo Vargas $^{1}$ (i) Marina Paula Lorenzett ${ }^{1}$ (D) Matheus Viezzer Bianchi ${ }^{1}$ (i)

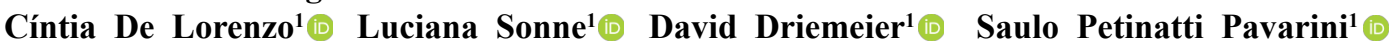

${ }^{1}$ Setor de Patologia Veterinária, Universidade Federal do Rio Grande do Sul (UFRGS), 90540-000, Porto Alegre, RS, Brasil, E-mail: francieliadrianemolossi@hotmail.com. "Corresponding author.

\begin{abstract}
Salmonellosis is a bacterial disease that affects several domestic animal species, and is commonly diagnosed in cattle, horses, and pigs. This study aimed to describe the epidemiological and pathological findings of eleven cases of enteric salmonellosis and two cases of salmonellosis with pulmonary involvement in cattle in Rio Grande do Sul State, Brazil. Clinical signs included fever, yellow diarrhea, sometimes with blood streaks, and dyspnea, with a clinical course ranging from 1 to 30 days. Eight cases occurred as outbreaks, whereas five cases occurred individually. Risk factors included inadequate handling practices, such as overcrowded facilities and comorbidities, including anaplasmosis. The main gross finding of the enteric presentation was fibrinonecrotic enterocolitis, occasionally associated with button ulcers, mesenteric lymphadenomegaly, splenomegaly, cholecystitis and hepatomegaly. In addition, one steer with a chronic clinical progression presented severe segmental thickening of the ileum, associated with intestinal rupture and peritonitis. In the respiratory system, the main findings were reddened, non-collapsed lungs, with multifocal areas of atelectasis. The main microscopic findings were observed in the small and large intestines, and these were characterized by severe necrosis and mucosal ulceration, associated with marked inflammatory infiltrate of neutrophils and fibrin deposition intermixed by rod-shaped bacterial aggregates, and fibrosis, as well as interstitial pneumonia. Seven cases yielded positive bacterial cultures for Salmonella spp. and three serovars, namely Typhimurium, Dublin, and Panama were identified. All cases exhibited immunolabeling for Salmonella spp. using immunohistochemistry.

Key words: pulmonary salmonellosis, fibrinonecrotic enteritis, cattle diarrhea, peritonitis.
\end{abstract}

Aspectos epidemiológicos e patológicos de salmonelose em bovinos no Sul do Brasil

RESUMO: Salmonelose é uma doença bacteriana que afeta inúmeras espécies animais, especialmente os bovinos, os equinos e os suínos. O presente estudo teve como objetivo descrever os aspectos epidemiológicos e patológicos de onze casos de salmonelose entérica e dois de salmonelose pulmonar em bovinos no estado do Rio Grande do Sul, Brasil. Os sinais clínicos incluíram febre, diarreia amarelada, por vezes com estrias de sangue, anorexia, perda de peso e dispneia, com curso clínico que variou de um a 30 dias. Em oito casos, a doença ocorreu em forma de surtos e cinco foram individuais. Identificou-se fatores de risco relacionados ao manejo inadequado com os bovinos, como alta lotação, além de comorbidades associadas, como anaplasmose. Os principais achados macroscópicos da forma entérica consistiram em enterocolite fibrinonecrótica, por vezes associada a formação de úlceras botonosas, linfonodos mesentéricos e baço aumentados, colecistite e hepatomegalia. Ainda, um bovino com quadro clínico crônico apresentou acentuado espessamento segmentar da parede do ileo associado a ruptura intestinal e peritonite. Na forma respiratória, os principais achados incluíram pulmões não colabados, avermelhados, com áreas multifocais de atelectasia. Os principais achados microscópicos foram observados no intestino delgado e grosso e foram caracterizados por acentuada necrose e ulceração da mucosa, associada a acentuado infiltrado inflamatório de neutrófilos e deposição de fibrina entremeada por agregados bacterianos cocobacilares e fibrose, além de pneumonia intersticial. Sete casos foram positivos para Salmonella sp. no cultivo bacteriano, com identificação dos sorovares Typhimurium, Dublin e Panama. Ao exame imuno-histoquímico para Salmonella sp. todos os casos apresentaram marcação positiva nos órgãos avaliados.

Palavras-chave: salmonelose pulmonar, enterite fibrinonecrótica, diarreia em bovinos, peritonite.

\section{INTRODUCTION}

Salmonellosis is a bacterial disease which affects several domestic animal species, mainly cattle (CUMMINGS et al., 2009; COSTA et al., 2012;
HOLSCHBACH \& PEEK, 2018), horses (JUFFO et al., 2017), and pigs (SILVA et al., 2006; UZAL et al., 2016), frequently leading to septicemia and enteric disorders (MOHLER et al., 2009). In cattle, clinical disease is predominantly caused by Salmonella 
enterica subsp. enterica serovar Typhimurium and $S$. enterica subsp. enterica serovar Dublin (CARRIQUEMAS et al., 2010; UZAL et al., 2016; PECORARO et al., 2017). The fecal-oral route represents the main route of transmission, and disease development is associated with bacterial efficiency in invading the intestinal mucosa, colonizing lymphoid tissues, and evading host immune response. The affected animals or asymptomatic carriers may spread the disease in the herd (PEEK et al., 2004; MOHLER et al., 2009).

Calves younger than 6-months of age are more vulnerable to the disease and may be infected a few hours after calving; nonetheless, adult cattle may also develop the clinical disease (NIELSEN, 2003; MOHLER et al., 2009). Salmonellosis in cattle is often characterized by watery or mucoid diarrhea containing fibrin and blood, septicemia, respiratory disease, weight loss, and abortions (NIELSEN, 2003; CARRIQUE-MAS et al., 2010). Lesions include enterocolitis, pneumonia, paratyphoid nodules in the liver, necrotic foci in the kidney, and splenomegaly (GELBERG, 2018). The aim of this study is to describe the epidemiological and pathological findings of thirteen cases of salmonellosis in Rio Grande do Sul State, Brazil. This paper describes the different forms of salmonellosis in cattle, as well as the identification of epidemiological factors and pathological changes, which is important for the prevention of salmonellosis. In addition, draws the attention of farmers and field veterinarians to include salmonellosis in the differential diagnosis of cattle with respiratory signs, without intestinal involvement.

\section{MATERIALS AND METHODS}

The database of the Department of Veterinary Pathology of the Universidade Federal do Rio Grande do Sul was assessed, and cases of bovine salmonellosis diagnosed between January 2008 and September 2019 were selected. This study included full necropsies only. Affected cattle were from farms located in the metropolitan area of Porto Alegre and the Northeast region of Rio Grande do Sul State, Brazil. Necropsy reports were retrieved and the following epidemiological information were recorded: age, breed, season of the year the case was diagnosed, clinical signs, disease progression (days), type of presentation (outbreak/individual case), septicemic or enteric presentation, and possible predisposing factors. Paraffin-embedded tissue blocks from these cases were retrieved, cut at $3 \mu \mathrm{m}$ thick sections, stained with hematoxylin and eosin, and evaluated under light microscopy. Some organ fragments, such as rumen, abomasum, and lungs, were also subjected to Grocott silver methenamine staining to reveal fungal structures. Gross and histopathological lesions were characterized according to the severity and location of the changes.

In eleven cases, culture and isolation of Salmonella spp. were attempted using fresh samples of large and small intestine, liver, lung, spleen, mesenteric lymph nodes, and bile. These samples were inoculated onto a medium containing 5\% sheep blood agar and MacConkey agar. In five of these cases, bacterial isolates were submitted for serotyping using a slide micro-agglutination test. Tissue sections of small and large intestines of all cases of enteric salmonellosis (11/13) and lung sections (4/13) were submitted for immunohistochemistry (IHC). The test was performed using a commercial polyclonal antibody against Salmonella spp. (Biogenesis ${ }^{\circledR}$ ), as previously described by JUFFO et al. (2017). Examination of tissue sections of small and large intestines was; however, modified to chromogen 3,30-diaminobenzidine (DAB, Sigma, St Louis, Missouri, USA). IHC was classified according to the presence or absence of immunostaining in the evaluated organs.

\section{RESULTS}

During the evaluated period, a total of 4,323 cattle necropsies were conducted, out of which eleven cases of enteric salmonellosis and two cases of salmonellosis with lung involvement were diagnosed. Epidemiological information of the affected cattle and the type of presentation of the disease are shown in table 1 . All cases occurred on farms with a semiintensive grazing system. The most commonly reported clinical signs were fever, yellow diarrhea (Figure 1A), sometimes with blood streaks, anorexia, emaciation, and in some cattle, dyspnea (4/13), and mucoid nasal discharge (2/13). Most affected cattle were treated with antibiotics and non-steroidal anti-inflammatory drugs, but no significant clinical improvement was observed.

Gross findings consisted of mild jaundice affecting the subcutaneous tissue (Figure 1B), oral mucosa, and ocular conjunctiva $(5 / 13)$. In all cases, there were segmental deposits of fibrinonecrotic material on the mucosa of the small and large intestines (Figure 1C-D), that often filled the intestinal lumen (fibrin casts) (Figure 1E). In two of these cases, button ulcers were also seen on the mucosa of the intestines (Figure 1F). The liver was enlarged, with round borders, diffusely orange coloration (Figure 
Table 1 - Epidemiological features of 13 cases of salmonellosis in cattle.

\begin{tabular}{|c|c|c|c|c|c|c|c|}
\hline $\begin{array}{l}\text { Cattle } \\
\text { number }\end{array}$ & Age & Breed & $\begin{array}{l}\text { Season } \\
\text { of death }\end{array}$ & $\begin{array}{l}\text { Clinical } \\
\text { course }\end{array}$ & $\begin{array}{c}\text { Type of } \\
\text { presentation }\end{array}$ & $\begin{array}{l}\text { Septicemic/enteric } \\
\text { presentation }\end{array}$ & Predisposing factor \\
\hline 1 & $30 \mathrm{~d}$ & Holstein & Spring & $7 d$ & Outbreak & Enteric & NI \\
\hline 2 & $15 \mathrm{~d}$ & Holstein & Fall & $4 d$ & Outbreak & $\begin{array}{c}\text { Septicemic with } \\
\text { enteric involvement }\end{array}$ & $\begin{array}{l}\text { Diet change from milk to } \\
\text { milk replacer }\end{array}$ \\
\hline 3 & $8 \mathrm{~m}$ & Hereford & Spring & $5 \mathrm{~d}$ & Individual & Enteric & NI \\
\hline 4 & $3 \mathrm{~m}$ & Angus & Fall & $4 d$ & Individual & $\begin{array}{c}\text { Septicemic with } \\
\text { enteric involvement }\end{array}$ & Early weaning \\
\hline 5 & $2.5 \mathrm{y}$ & $\begin{array}{l}\text { Mixed } \\
\text { breed }^{*}\end{array}$ & Winter & $7 \mathrm{~d}$ & Individual & Enteric & Transportation \\
\hline 6 & $4 \mathrm{~m}$ & Angus & Fall & $3 d$ & Outbreak & Enteric & NI \\
\hline 7 & $3 \mathrm{~m}$ & Angus & Summer & $14 \mathrm{~d}$ & Individual & $\begin{array}{c}\text { Septicemic with } \\
\text { enteric involvement }\end{array}$ & Overcrowded facilities \\
\hline 8 & $20 \mathrm{~d}$ & Holstein & Winter & $3 d$ & Outbreak & Enteric & Overcrowded facilities \\
\hline 9 & $2.5 \mathrm{y}$ & Holstein & Fall & $1 d$ & Outbreak & Enteric & NI \\
\hline 10 & $2 \mathrm{y}$ & Holstein & Summer & $4 d$ & Individual & Enteric & $\begin{array}{c}\text { Acute poisoning by } \\
\text { Pteridium arachnoideum }\end{array}$ \\
\hline 11 & $8 \mathrm{~m}$ & Guzerá & Spring & $30 \mathrm{~d}$ & Outbreak & Enteric & NI \\
\hline 12 & $6 \mathrm{~m}$ & Brangus & Summer & $3 d$ & Outbreak & $\begin{array}{l}\text { Septicemic without } \\
\text { enteric involvement }\end{array}$ & Concomitant anaplasmosis \\
\hline 13 & $6 \mathrm{~m}$ & Angus & Summer & $3 d$ & Outbreak & $\begin{array}{l}\text { Septicemic without } \\
\text { enteric involvement }\end{array}$ & Concomitant anaplasmosis \\
\hline
\end{tabular}

d: days; m: months; y: years. NI: not identified.

*Beef cattle.

$1 \mathrm{~B}$ and $2 \mathrm{~A})$, and intermixed with multifocal, well circumscribed pale-yellow areas (8/13). In two cases, wherein anaplasmosis was concomitantly detected, the gallbladder was distended and filled with grumous bile (Figure 2B-C). In addition, extensive fibrin deposits were observed within the gallbladder, associated with mucosal ulceration (5/13) (Figure 2D). Mesenteric lymph nodes were severely enlarged and had edema on the cut section (8/13) (Figure $3 \mathrm{~A})$. The spleen was also severely enlarged, with round borders (4/13). Lungs were diffusely red, non-collapsed, with a rubbery texture, and presented interlobular edema on the cut surface (Figure $3 \mathrm{~B}$ and $3 \mathrm{C})$. In the cranioventral areas of the lung and ventral portion of the caudal lobes, multifocal red-tan and firm areas were observed (4/13) (Figure 1B and 3C).

In addition, case 11 presented severe wall thickening and luminal stenosis in a segmental area of the ileum. In this section, the intestinal mucosa was moderately irregular and had multifocal dark areas as well as a focal area of mucosal ulceration and perforation, which showed raised and dark borders (Figure 3D). In this case, mild passage of intestinal contents to the abdominal cavity was observed, associated with fibrin deposition and adhesions along the serosa of the intestines, the mesenterium, and the peritoneum. In case 7 , peritonitis secondary to intestinal rupture was also observed, however, no apparent segmental stenosis was seen. No other significant alterations were observed in gross examination.

Microscopic examination revealed that in five cases intestinal lesions was observed only in the jejunum and ileum, while in the other six cases, lesions were distributed through jejunum, ileum, cecum and colon. These intestinal lesions were characterized by multifocal areas of marked transmural necrosis and mucosal ulceration. These were associated with fibrin deposition (Figure 4A) and severe inflammatory infiltration of intact and degenerate neutrophils, lymphocytes, plasma cells, and macrophages that were intermixed with rod-shaped bacterial aggregates, predominantly visualized on the surface of the lesion (11/13). Further examination of the tissues showed multifocal moderate thrombosis and vasculitis in the intestines (4/13) and marked transmural fibrous connective tissue proliferation in the ileum of case 11. The liver had multiple paratyphoid nodules, characterized by multifocal areas of marked hepatic necrosis, with intact and degenerate neutrophils, 


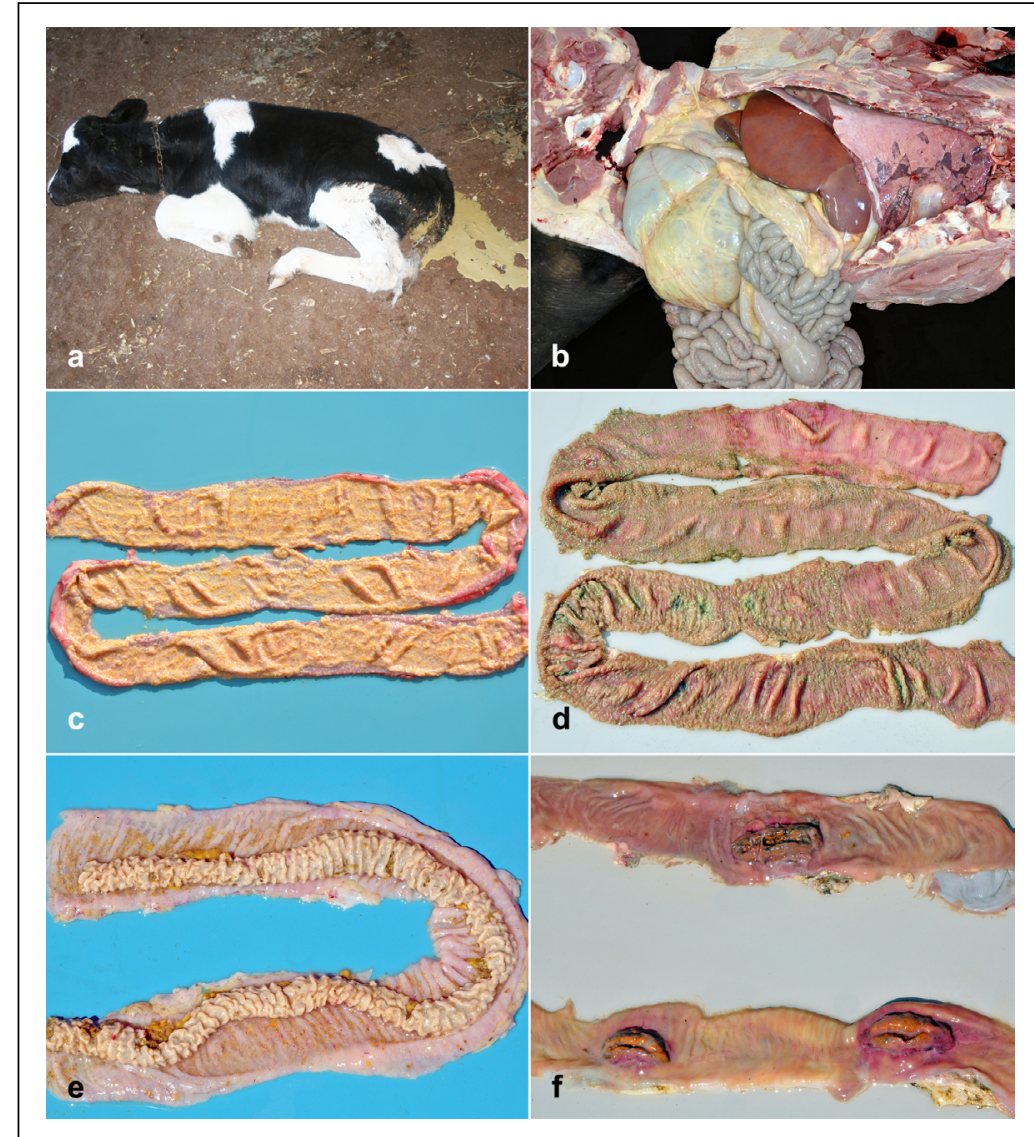

Figure 1 - Pathological findings of salmonellosis in cattle in southern Brazil. (A) Calf presenting yellow diarrhea. (B) Cattle. The liver is enlarged, with rounded edges, and light orange discoloration. In addition, multifocal red-tan areas of atelectasis are seen in the cranial, middle and caudal lung lobes. (C) Small intestine segment presenting fibrinonecrotic contents covering the mucosa. (D) Small intestine segment presenting mild thickening, red discoloration and multifocal ulcers in the mucosa. (E) A fibrin cast has filled the intestinal lumen and, thus, acquired the anatomic form of the organ. (F) Segments of intestinal wall presenting multifocal dark-red areas and button ulcers in the de mucosa.

lymphocytes, and fibrin deposits (Figure 4B). Additional pathological changes included fibrinoid necrosis of blood vessels and moderate multifocal thrombosis, sometimes with aggregates of rod-shaped bacteria and cholestasis (9/13). Regarding pulmonary pathological changes, the lungs of four cases had severe inflammatory infiltration of macrophages, lymphocytes, and neutrophils, which expanded the alveolar septa and filled the alveolar spaces (Figure 4C-D). Additionally, pulmonary necrosis with thrombosis, deposition of fibrin and cellular debris, as well as foamy macrophages were seen in the lumen of bronchi, bronchioles, and alveolar spaces of cases 12 and 13. In these cases, moderate thickening of the alveolar septa due to type II pneumocyte hyperplasia and rare multinucleated syncytial cells were also seen. In the gallbladder, mucosal necrosis associated with mixed inflammatory infiltrate was detected (4/13). Moderate necrotic foci were also observed in the spleen (6/13). Similar necrotic foci were observed in the mesenteric lymph nodes (5/13), concomitant with diffuse and moderate edema (3/13). Grocott silver methenamine staining evidenced in case 2 , occasional intralesional fungal structures in the rumen and abomasum mucosal surfaces suggestive of Candida spp, while the lungs were negative to this staining. No other significant histopathology lesions were observed. 


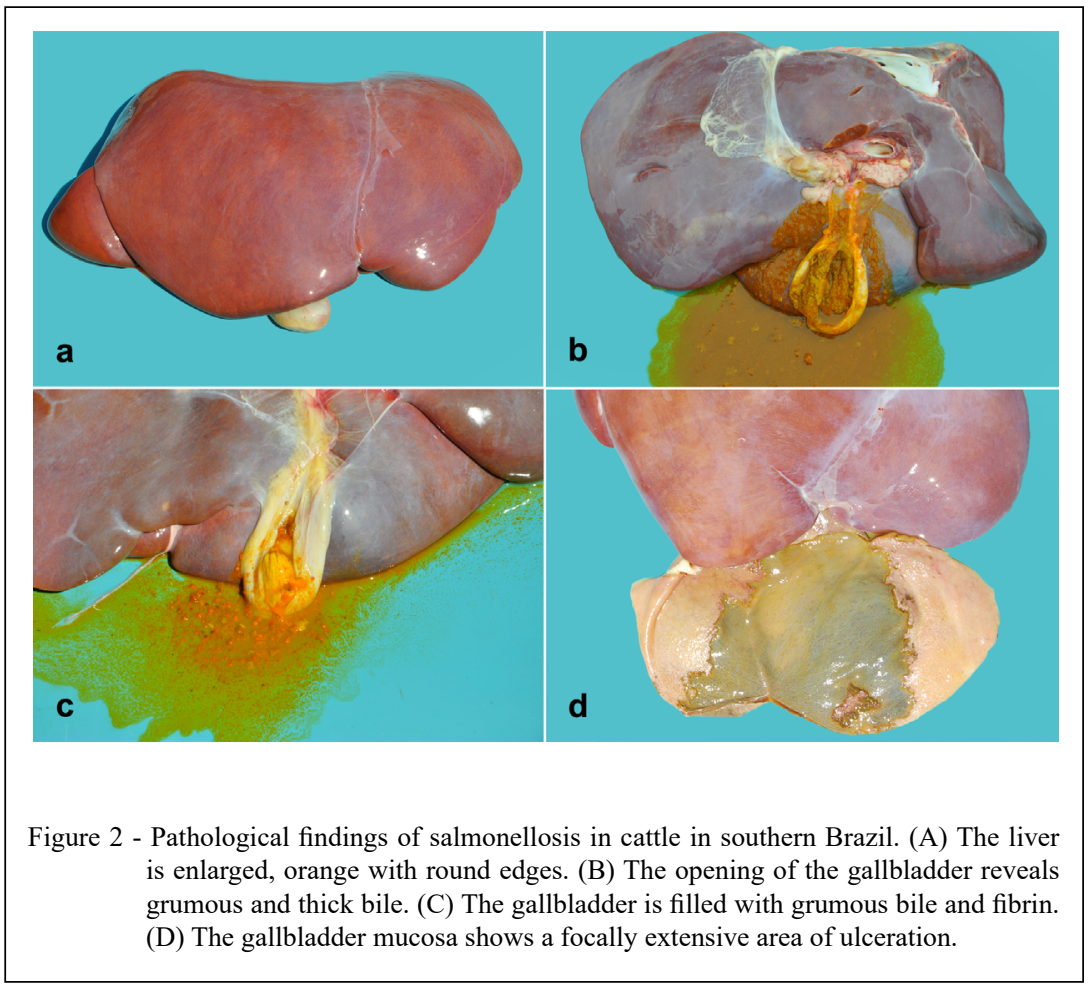

IHC revealed positive immunolabeling for all 13 cases. Marked immunolabeling of the bacteria was seen, and these were observed predominantly freely in the mucosal lining, mainly at the tip of villi and intermixed with areas of fibrin deposition in 11 of 13 cases (Figure 4E). Mild cytoplasmic labeling was detected in lung macrophages and pulmonary interstitial space in 4 of the 13 cases (Figure 4F). Salmonella spp. were isolated in seven out of eleven cases that were cultured, and five isolates were successfully serotyped. Salmonella Panama was identified in case 2, whereas Salmonella Typhimurium, and Salmonella Dublin were isolated in cases 4 and 7 and cases 12 and 13, respectively. The two cases of fibrinous cholecystitis were identified as serovar Salmonella Typhimurium.

\section{DISCUSSION}

The diagnosis of salmonellosis in cattle in this study was based on the association of the gross, microscopic, immunohistochemical, and microbiological findings. Predisposition for Salmonella spp. infection in cattle may be due to certain individual factors, such as age and physiological stage (NIELSEN, 2003). For example, calves aged $<14$ days benefit from immune protection provided by the colostrum antibodies, but this passive immunity is not long-lasting (MARQUES et al., 2013; NIELSEN, 2003). In the present study, the youngest affected animal was a 2-week-old calf, and the vulnerability to salmonellosis was probably related to early weaning and a diet switch from milk to milk replacer. This calf also presented with opportunistic fungal infection, which may indicate that passive immunity by colostrum antibodies was insufficient.

Adult cattle may act as the source of infection for calves (CARRIQUE-MAS et al., 2010); however, animals in this age group may also present clinical salmonellosis progressing to death (NIELSEN, 2003; MOHLER et al., 2009), as observed in three adult cattle in this study, in which possible predisposing factors included transportation and concomitant diseases. Potential predisposing factors include concomitant diseases, that may lead to stress and immunosuppression, which may favor the development of clinical disease or may propitiate cattle to become asymptomatic carriers (NIELSEN, 2003). In this study, comorbidities were detected in four cases and the specific diseases were anaplasmosis, acute poisoning by Pteridium arachnoideum and fungal ruminitis.

Ciência Rural, v.51, n.3, 2021. 


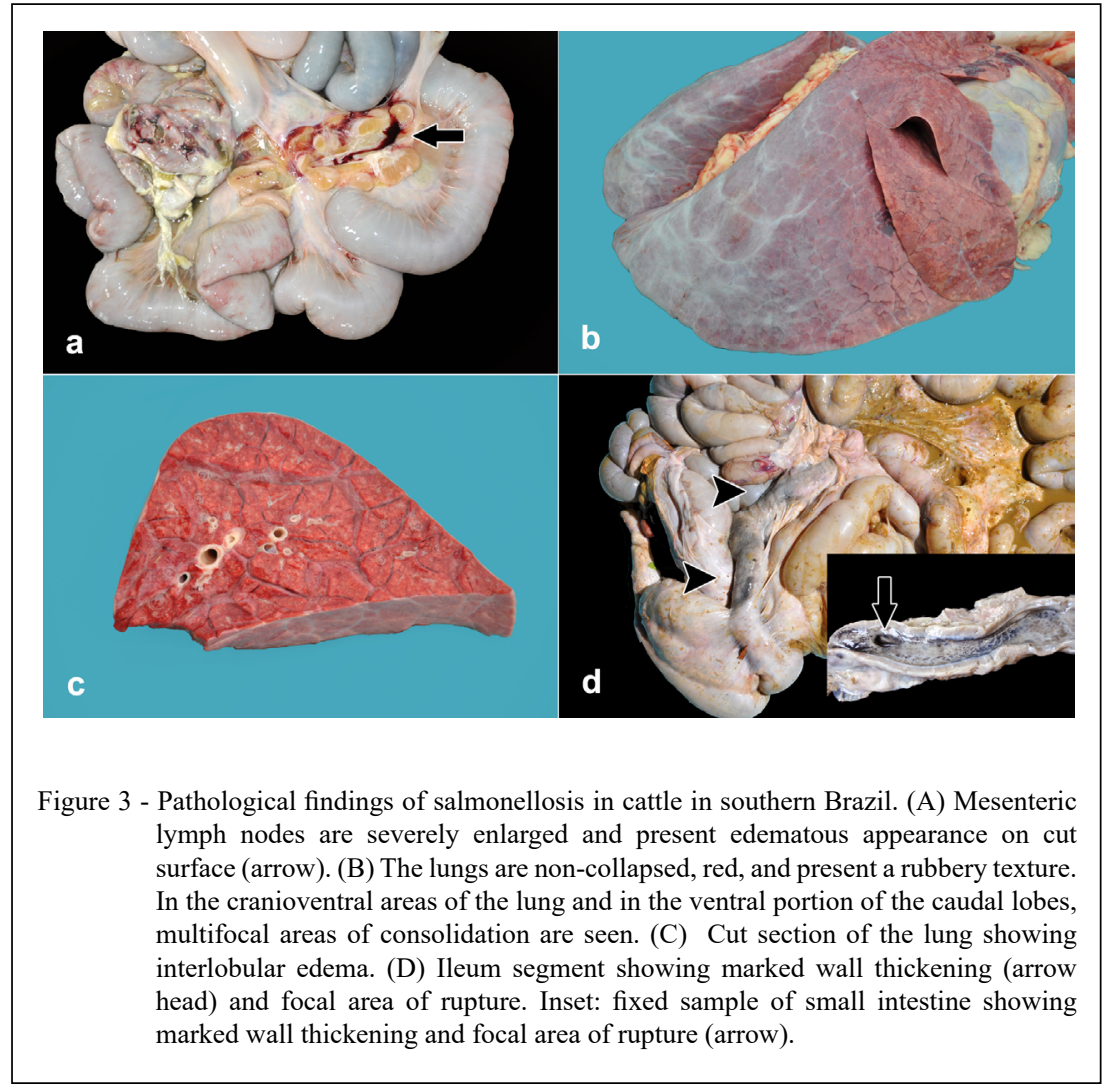

Additionally, we observed that beef cattle were the most affected group (8/13); however, salmonellosis can occur in both beef and dairy cattle (BLANCHARD, 2012). The occurrence of the infection is frequently related to predisposing factors and management practices used in the farms (MOHLER et al., 2009; BLANCHARD, 2012). The onset and progression of salmonellosis may be associated with intrinsic bacterial factors, such as strain virulence, pathogenicity, and resistance to antibiotics, besides that, the genetic composition of the host can influence its susceptibility to the disease (NIELSEN, 2003). Other potential risk factors include type and quality of feed, quality of water and air, environmental hygiene, tool contamination, type of housing, and ventilation in the facilities, and transportation may influence the infection pressure (NIELSEN, 2003). According to CARRIQUEMAS et al. (2010), overcrowding is the single most important risk factor related to disease development. Some environmental factors and inadequate management practices were identified in the current study and considered as primary stressor events, which may have compromised the immune system and ultimately led to the death of the affected cattle. The season of the year can also influence the risk of the animals becoming infected, more frequently observed in the late winter until spring (NIELSEN, 2003); however, we did not observed that, since the salmonella deaths occurred in all seasons over the 10 years evaluated. The type of presentation of salmonellosis is mainly related to the previously described risk factors, and this disease may occur as individual cases or outbreaks, with the latter being more common (NIELSEN, 2003). This is corroborated by our findings, since most necropsies were conducted in animals (8/13) that were originally from farms that had previously reported similar deaths (outbreaks).

Gross lesions characterized predominantly by fibrinonecrotic enteritis, affecting more severely the ileum, are commonly observed in acute salmonellosis in cattle (UZAL et al., 2016). In the current study, these lesions had a multifocal distribution and were observed in all intestinal segments. Fibrinous cholecystitis is considered a characteristic lesion of salmonellosis in cattle (MOHLER et al., 2009). Furthermore, lymphadenopathy of mesenteric lymph 


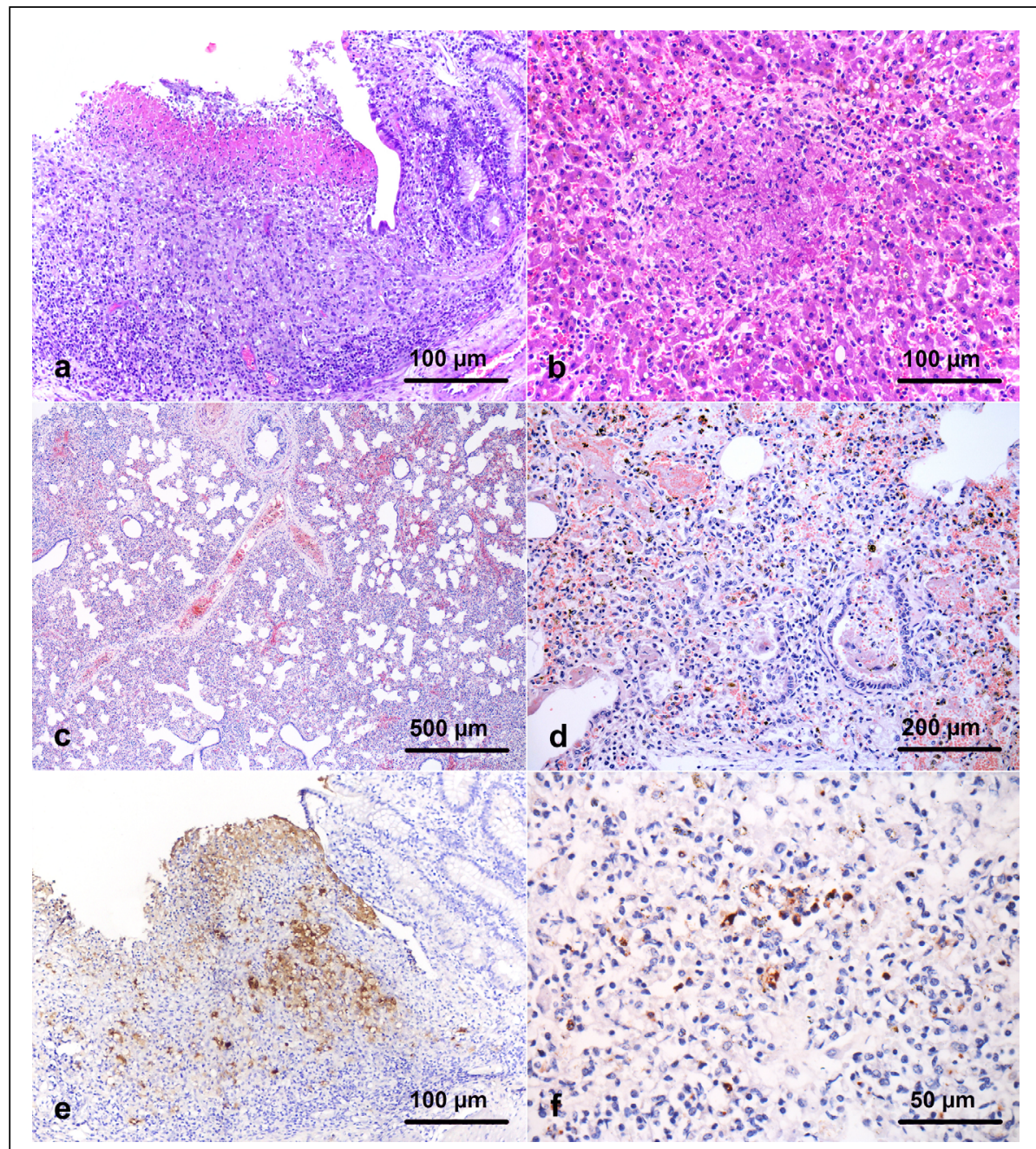

Figure 4 - Pathological findings of salmonellosis in cattle in southern Brazil. (A) Small intestine presenting mucosal necrosis and ulceration, associated with inflammatory infiltrate of neutrophils, lymphocytes, plasma cells, and macrophages, as well as abundant fibrin deposition (H\&E, bar: $100 \mu \mathrm{m})$. (B) Liver presenting a focally extensive area of necrosis associated with fibrin deposition intermixed by inflammatory infiltrate of macrophages and neutrophils (paratyphoid nodules) (H\&E, bar: $100 \mu \mathrm{m})$. (C) Lung: alveolar septa are expanded by macrophages, lymphocytes, and neutrophils (H\&E, bar: $500 \mu \mathrm{m})$. (D) Alveolar septa and spaces are markedly infiltrated by macrophages, lymphocytes, and plasma cells, associated with fibrin deposition (H\&E, bar: $200 \mu \mathrm{m}$ ). (E) Marked immunolabeling is seen in the lining of the intestinal mucosa. Moreover, bacteria are observed freely in the intestinal lumen (IHC, bar: $100 \mu \mathrm{m}$ ) (F) Mild immunolabeling is noted within the cytoplasm of macrophages and freely within the lung (IHC, bar: $50 \mu \mathrm{m}$ ).

nodes, hepatomegaly, and splenomegaly suggest septicemic salmonellosis (MARQUES et al., 2013). Most of these lesions were observed in the reported case series and are similar to those described previously. Only two cattle presented button ulcers, which showed a multifocal distribution in the intestinal mucosa. In addition, one animal presented stenosis of the ileum. The stenosis is classified as a chronic lesion of salmonellosis, in which the basement membrane is affected; consequently, causing direct damage to the blood vessels in this organ. Nonetheless, it is possible that button ulcers occur 
in association with septicemic salmonellosis, and that bacterial adherence to the vessel endothelium elicits vasculitis, thrombosis, ischemia, and infarcts (UZAL et al., 2016). Moreover, chronic lesions of salmonellosis may result in the thickening of the intestinal wall (MOHLER et al., 2009). This description is in accordance with the present findings, wherein marked segmental thickening of the ileum wall was associated with an area of intestinal rupture.

Salmonella Typhimurium may cause septicemia and is commonly detected in outbreaks of enteric disease in calves. In contrast, $S$. Dublin, a hostadapted serovar in cattle, is predominantly associated with septicemia across all age groups in cattle (UZAL et al., 2016). An outbreak of septicemic salmonellosis with lung involvement has been described in the North region of Brazil associated with serovar Dublin (MARQUES et al., 2013). In addition, salmonellosis with primary lung involvement, in the absence of enteric lesions, has been reported in the Central-West region of Brazil (GUIZELINI et al., 2019). Similarly, in the present case series, two 6-month-old steers had interstitial pneumonia wherein $S$. Dublin was isolated in the absence of intestinal lesions. Likewise, a study conducted in the United States of America reported similar lung lesions in young cattle (PECORARO, et al., 2017).

In humans, $S$. Panama has been associated with severe septicemic disease (enterocolitis, bacteremia, and meningitis) in children up to 15 months of age. In addition, it has been isolated from feed and water (CORDANO \& VIRGILIO, 1996; NÖEL et al., 2010). This serovar has rarely been described in cattle, but previous reports in Argentina show it can cause diarrhea in calves (BELLINZONI et al., 1990). In this study, $S$. Panama-associated disease occurred as an outbreak of severe septicemic disease, with enteric and respiratory involvement. Clinical presentation was associated with lesions affecting the small and large intestines, lungs, liver, and mesenteric lymph nodes (case 2), similarly to what has been previously described in humans (CORDANO \& VIRGILIO, 1996; NÖEL et al., 2010).

In four cattle, no bacterial growth was detected in the cultured tissues. This may be due to prior systemic therapy with antibiotics as well as growth suppression by the normal intestinal microbiota in the enrichment broth. In addition, bacterial culture and isolation of Salmonella spp. from necropsy samples may be negatively affected by bacterial proliferation in tissues after the death of the animal (BLANCHARD, 2012).
Molecular techniques, such as polymerase chain reaction (PCR), are useful tools for investigating cases of salmonellosis, especially in cases of low bacterial count; therefore, this diagnostic method may help to identify carriers of the disease (MOUSSA et al., 2010; GUIZELINI et al., 2020). Nonetheless, in this study, IHC was used to confirm Salmonella spp. tissue colonization. IHC is an important diagnostic tool (NIELSEN, 2003; RIEGER et al., 2015), especially when bacterial isolation is not possible, as some of the cases observed in the current study, and frozen tissues for PCR are no longer available.

\section{CONCLUSION}

Salmonellosis represents an important cause of enteric, respiratory, and systemic disease in cattle in southern Brazil. Several possible predisposing factors were observed and included prior stressor events and comorbidities, such as anaplasmosis. The disease occurred more frequently in outbreaks, and gross lesions included multifocal fibrinonecrotic enteritis, segmental thickening of the ileum, and interstitial pneumonia. $S$. Dublin was diagnosed in cases of interstitial pneumonia without enteric changes. S. Panama, which is not a frequently diagnosed agent, was identified in cases of systemic salmonellosis. Besides that, $S$. Typhimurium was also an identified serovar. Finally, IHC represented an important diagnostic technique, since positive immunolabeling was detected even in cases where bacterial culture was not achieved.

\section{ACKNOWLEDGMENTS}

We thank CNPq (Conselho Nacional de Desenvolvimento Científico e Tecnológico) and CAPES (Coordenação de Aperfeiçoamento de Pessoal de Nível Superior) for financial support.

\section{BIOETHICS AND BIOSECURITY COMMITTEE APPROVAL DECLARATION}

We authors of the article entitled "Epidemiological and pathological aspects of salmonellosis in cattle in southern Brazil" declared, for all due purposes, the project that gave rise to the present data of the same has not been submitted for evaluation to the Ethics Committee of the Universidade Federal do Rio Grande do Sul, but we are aware of the content of the Brazilian resolutions of the National Council for Control of Animal Experimentation - CONCEA "http://www.mct.gov.br/ index.php/content/view/310553.html" if it involves animals. Thus, the authors assume full responsibility for the presented data and are available for possible questions, should they be required by the competent authorities. 


\section{DECLARATION OF CONFLICT OF INTERESTS}

The authors declared no potential conflicts of interest with respect to the research, authorship, and/or publication of this article.

\section{AUTHORS' CONTRIBUTIONS}

All authors contributed equally for the conception and writing of the manuscript. All authors critically revised the manuscript and approved of the final version.

\section{REFERENCES}

BELLINZONI, R. C. et al. Microbiology of diarrhea in young beef and dairy calves in Argentina. Revista Argentina de Microbiologia, v.22, p.130-137, 1990. Available from: <file://C:/ Users/cliente/Downloads/MicrobiologyofdiarrhoeaincalvesRev. Arg.Microbiol.2231301361990.pdf>. Accessed: May, 17, 2020.

BLANCHARD, P. C. Diagnostics of dairy and beef cattle diarrhea Veterinary Clinics of North America: Food Animal Practice v.28, p.443-464, 2012. Available from: $<$ https://www.sciencedirect. com/science/article/pii/S0749072012000539?via\%3Dihub>. Accessed: May, 17, 2020. doi: 10.1016/j.cvfa.2012.07.002.

CARRIQUE-MAS, J. J. et al. Salmonella infection in cattle in Great Britain, 2003 to 2008. Veterinary Record, v.167, p.560565, 2010. Available from: <https://veterinaryrecord.bmj.com/ content/167/15/560.long>. Accessed: May, 17, 2020. doi: 10.1136/ vr.c4943.

CORDANO, A. M. \& VIRGILIO, R. Evolution of drug resistance in Salmonella panama isolates in Chile. Antimicrobial Agents and Chemotherapy, v.40, n.2, p.336-341, 1996. Available from: <https://www.ncbi.nlm.nih.gov/pmc/articles/PMC163112/ pdf/400336.pdf $>$. Accessed: May, 17, 2020. doi: 10.1128/ AAC. 40.2 .336

COSTA, L. F. et al. Salmonellosis in cattle: advantages of being an experimental model. Research in Veterinary Science, v.93, p. 1-6 2012. Available from: <https://www.sciencedirect.com/science/ article/abs/pii/S0034528812000823?via\%3Dihub>. Accessed: May, 17, 2020. doi: 10.1016/j.rvsc.2012.03.002.

CUMMINGS, K. J. et al. The incidence of salmonellosis among dairy herds in the northeastern United States. Journal of Dairy Science, v.92, p.3766-3774, 2009. Available from: <https:// www.journalofdairyscience.org/article/S0022-0302(09)70698-8/ fulltext>. Accessed: May, 17, 2020. doi: 10.3168/jds.2009-2093.

GELBERG, H. B. Alimentary system and the peritoneum, omentum, mesentery, and peritoneal cavity. In: JF ZACHARY, Pathologic Basis of Veterinary Disease, 2018, 6.ed. SaintLouis, Missouri: Elsevier, 324-411.

GUIZELINI, C. C. et al. Salmonellosis in calves without intestinal lesions. Pesquisa Veterinária Brasileira, v.39, n.8, p.580-586, 2019. Available from: <https://www.scielo.br/scielo. php? script $=$ sci_arttext\&pid=S0100-736X2019000800580>. Accessed: May, 17, 2020. doi: 10.1590/1678-5150-pvb-6328.

GUIZELINI, C. C. et al. Outbreak investigation of septicemic salmonellosis in calves. The Journal of Infection in Developing
Countries, v.14, n.1, p.104-108, 2020. Available from: <https:// jidc.org/index.php/journal/article/view/32088691/2192>. Accessed: May, 17, 2020. doi: 10.3855/jidc. 12087 .

HOLSCHBACH, C. L. \& PEEK, S. F. Salmonella in dairy cattle. Veterinary Clinics of North America: Food Animal Practice, v.34, p.133-154, 2018. Available from: $<$ https://www.sciencedirect. com/science/article/pii/S0749072017300853?via\%3Dihub $>$. Accessed: May, 17, 2020. doi: 10.1016/j.cvfa.2017.10.005.

JUFFO, G. D. et al. Equine salmonellosis in southern Brazil. Tropical Animal Health and Production, v.49, p.475-482, 2017. Available from: $<$ https://link.springer.com/article/10.1007/s11250016-1216-1>. Accessed: May, 17, 2020. doi: 10.1007/s11250-0161216-1.

MARQUES, A. L. A., et al. Salmonellosis outbreak by serovar Dublin in calves in Maranhão. Pesquisa Veterinária Brasileira v.33, n.8, p.983-988, 2013. Available from: <https://www.scielo. br/pdf/pvb/v33n8/06.pdf>. Accessed: May, 17, 2020. doi: 10.1590/ S0100-736X2013000800006.

MOHLER, V. Let al. Salmonella in calves. Veterinary Clinics of North America: Food Animal Practice, v.25, p.37-54, 2009 Available from: <https://www.sciencedirect.com/science/article/ abs/pii/S0749072008000923?via\%3Dihub. Accessed: May, 17, 2020. doi: 10.1016/j.cvfa.2008.10.009.

MOUSSA, I. M., et al. Rapid detection of Salmonella species in newborn calves by polymerase chain reaction. International Journal of Genetics and Molecular Biology, v.2, n.4, p.062066, 2010. Available from: <file:///C:/Users/cliente/Downloads/ Rapid_detection_of_Salmonella_species_in_newborne_\%20(1). pdf $>$. Accessed: $\bar{M}$ ay, 17, 2020. doi: $10.10 \overline{16} / \overline{\mathrm{j}} \cdot \mathrm{mcp} .2004 .05 .003$.

NIELSEN, L. R. Salmonella Dublin in dairy cattle: use of diagnostic tests for investigation of risk factors and infection dynamics. 219 p. PHD thesis - Department of Animal Science and Animal Health, Royal Veterinary and Agricultural University, Denmark, 2003.

NÖEL, H. et al. Consumption of fresh fruit juice: how a healthy food practice caused a national outbreak of Salmonella Panama gstroenteritis. Foodborne Pathogens and Disease, v.7, n.4, p.375381, 2010. Available from: <file://C:/Users/cliente/Downloads/ Noel Fresh Juice Salmo.pdf $>$. Accessed: May, 17, 2020. doi: $10.1089 / \mathrm{fpd} . \overline{2009.0330}$

PECORARO, H. L., et al. Histopathology case definition of naturally acquired Salmonella enterica serovar Dublin infection in young Holstein cattle in the northeastern United States. Journal of Veterinary Diagnostic Investigation, v.29, n.6, p.860-864, 2017. Available from: <https://journals.sagepub.com/doi/full/10.1177/1 040638717712757?url_ver=Z39.882003\&rfr_id=ori:rid:crossref. org\&rfr_dat $=$ cr_pub\%3dpubmed $>$. Accessed: May, 17, 2020. doi: $10.1177 / 1040638717712757$.

PEEK, S. F. et al. Isolation of Salmonella spp from the environment of dairies without any history of clinical salmonellosis. Journal of the American Veterinary Medical Association, v.225, n.4, p.574577, 2004. Available from: <https://avmajournals.avma.org/doi/ abs/10.2460/javma.2004.225.574>. Accessed: May, 17, 2020. doi: 10.2460/javma.2004.225.574.

RIEGER, J. et al. Enhancement of immunohistochemical detection of Salmonella in tissues of experimentally infected 
pigs. European Journal of Histochemistry, v.59, p.5-11, 2015. Available from: <https://www.ncbi.nlm.nih.gov/pmc/articles/ PMC4598596/>. Accessed: May, 17, 2020. doi: 10.4081/ ejh.2015.2516.

SILVA, L. E. et al. Salmonella enterica infection in pigs reared in an integrated production system in southern Brazil. Arquivo Brasileiro de Medicina Veterinária e Zootecnia, v.58, n.4, p.455-461, 2006. Available from: <https://www.scielo.br/scielo. php?script=sci_arttext\&pid=S010209352006000400001\&lng= es\&nrm=iso\&tlng=pt $>$. Accessed: May, 17, 2020. doi: 10.1590/ S0102-09352006000400001.

UZAL, F. A., et al. Alimentary System. In: M. G Maxie. Pathology of Domestic Animals, Jubb, Kennedy \& Palmer's. 6.ed. St. Louis, Missouri: Elsevier, 2, 117-176, 2016. 